\title{
HUBUNGAN MINAT BELAJAR DENGAN HASIL BELAJAR FISIKA MELALUI MODEL PROJECT BASED LEARNING DI KELAS XI MIPA SMAN 6 KOTA BENGKULU
}

\author{
Endah Tri Wahyuningsih*, Andik Purwanto, Rosane Medriati
}

Program Studi S1 Pendidikan Fisika Universitas Bengkulu

Jalan WR. Supratman, Kandang Limun Bengkulu e-mail*: endahtw7@gmail.com

\begin{abstract}
ABSTRAK
Penelitian ini bertujuan untuk menentukan ada tidaknya hubungan signifikan antara minat belajar dengan hasil belajar fisika siswa melalui model Project Based Learning (PjBL) pada siswa kelas XI MIPA SMA Negeri 6 Kota Bengkulu. Jenis penelitian yang digunakan adalah penelitian Quasi Experimental dengan desain penelitian one-group pretestposttest. Sampel penelitian diambil menggunakan tekn ik purposive sampling yang sebelumnya telah diuji normalitas diperoleh siswa kelas XI MIPA D sebagai kelas uji coba (eksperimen). Teknik pengumpulan data menggunakan angket untuk minat belajar fisika dan tes untuk hasil belajar fisika. Analisis data diuji menggunakan analisis korelasi product moment. Uji prasyarat analisis data berupa uji normalitas. Berdasarkan analisa data diperoleh kesimpulan bahwa terdapat hubungan positif yang signifikan antara minat belajar dengan hasil belajar fisika siswa melalui pembelajaran Project Based Learning (PjBL) pada siswa kelas XI MIPA SMA Negeri 6 Kota Bengkulu. yang ditunjukkan dari nilai $r_{\text {hitung }}$ yang lebih besar dari $r_{\text {tabel }}(0,660>0,479)$ dengan kontribusi minat sebesar 43,56\% dengan indikator minat yang paling besar pengaruhnya adalah indikator perasaan senang dengan nilai korelasi rata-rata sebesar 0,669 sehingga dapat disimpulkan bahwa terdapat hubungan yang signifikan antara minat belajar dan hasil belajar siswa.
\end{abstract}

Kata kunci :hubungan, minat belajar, hasil belajar, project based learning model

\section{ABSTRACT}

This research aimed to determine whether there is a significant relationship between learning interest and student physics learning outcomes through Project Based Learning Model (PjBL) in class XI MIPA students of SMA Negeri 6 Bengkulu City. This type of research was a Quasi Experimental study with a one-group pretest-posttest research design. The research sample was taken using a purposive sampling technique that had previously been tested for normality obtained by students of class XI MIPA D as a experimental class. Data collection techniques were using a questionnaire for interest in learning physics and tests for learning outcomes in physics. Data analysis was tested using product moment correlation analysis. The prerequisite test for data analysis was the normality test. Based on data analysis, it can be concluded that there is a significant positive relationship between learning interest and student physics learning outcomes through Project Based Learning (PjBL) learning in class XI MIPA students of SMA Negeri 6 Bengkulu City. which is shown from a value greater than (0.660>0.374) with an interest contribution of $43.56 \%$ with the most influential interest indicator being an indicator of feeling happy with an average correlation value of 0.669 so it can be concluded that there is a significant relationship between interests learning and student learning outcomes.

Keywords: Correlation, interest in learning, Learning Outcomes, project based learning models,

\section{PENDAHULUAN}

Pendidikan merupakan usaha terencana dan sadar serta bertujuan untuk mewujudkan suasana belajar dan proses pembelajaran peserta didik agar secara aktif dapat mengembangkan potensi dirinya untuk memiliki kekuatan spiritual keagamaan, pengendalian diri, kepribadian, kecerdasan, akhlak mulia, serta keterampilan yang diperlukan dirinya dan masyarakat (1). Tujuan utama dalam pengelolaan proses pendidikan Bukan semata-mata hanya untuk memperoleh hasil belajar, tetapi untuk mencapai pelaksanaan belajar secara optimal dan proses belajar yang baik, maka harus ada 
suatu kegiatan pembelajaran serta komponen yang mendukung dalam kegiatan pembelajaran tersebut. Komponen pembelajaran tersebut terdiri dari tujuan pembelajaran, materi pembelajaran, metode pembelajaran, media pembelajaran dan evaluasi pembelajaran (2).

Pendidikan tinggi harus mengupayakan untuk mengantisipasi perubahan dinamis yang pesat dalam pendidikan. Salah satu cara untuk melakukannya adalah dengan mengadaptasi konsep pembelajaran abad ke-21. Konsep abad ke-21 belajar ditandai dengan pelatihan dan pengembangan keterampilan, baik dalam keterampilan belajar dan inovasi, dan juga keterampilan informasi, media dan teknologi. Pembelajaran fisika sebagai bagian dari pendidikan sains memiliki peran strategis dalam mengembangkan pendidikan abad ke-21. Dalam pembelajaran fisika, Keterampilan abad ke21 dapat dikembangkan dengan proses pembelajaran di kelas dan kegiatan ekperimen (3). kegiatan eksperimental adalah bagian penting dari pembelajaran fisika yang dapat memberi siswa langsung pengalaman dalam menerapkan metode ilmiah (4). Fisika merupakan salah satu cabang ilmu pengetahuan alam (IPA) yang mendasari perkembangan teknologi dan konsep hidup harmonis dengan alam. Fisika juga merupakan ilmu yang mempelajari tentang materi dan zat yang meliputi sifat komposisi, perubahan dan energi yang dihasilkan. Oleh karena itu, perkembangan ilmu pengetahuan dan teknologi yang sangat pesat saat ini tidak lepas dari ilmu Fisika sebagai salah satu ilmu dasar (5).

Hasil observasi awal di kelas XI MIPA SMA Negeri 6 Kota Bengkulu. Khusunya untuk mata pelajaran fisika masih banyak permasalahan dalam proses pembelajaran Fisika yang berlangsung. Permasalahan tersebut berupa masih kurangnya minat belajar dan hasil belajar siswa terhadap materi yang diajarkan dan siswa yang kurang aktif saat kegiatan pembelajaran. Indikator kurangnya minat dapat dilihat pada proses pembelajaran adalah perhatian, perasaan senang, ketertarikan, dan keterlibatan. Secara umum, selama proses pembelajaran peserta didik sering mengeluh jika jam pelajaran fisika sudah tiba sehingga proses pembelajaran harus dimulai, ketika proses pembelajaran sedang berlangsung kebanyakan peserta didik hanya menerima materi yang diberikan guru, tidak antusias dalam mencari pengetahuan secara mandiri. Respon siswa masih dapat dikatakan rendah berdasarkan pengamatan yang telah dilakukan. Proses pembelajaran juga masih berlangsung satu arah karena guru bidang studi fisika yang mengajar di kelas. Selain itu, permasalahan yang telah diuraikan tersebut berpengaruh pada hasil ulangan harian kelas XI hampir 50\% siswa belum tuntas atau mendapat nilai di bawah KKM. Bukan hanya nilai ulangan harian, tetapi untuk nilai pada proses Penilaian Tengah Semester (PTS) juga menunjukkan siswa mendapat nilai di bawah KKM.

Rendahnya kedua aspek tersebut dapat disebabkan oleh penggunaan model pembelajaran yang kurang tepat. Untuk mengatasi permasalahan yang dihadapi pada pembelajaran fisika, perlu adanya perubahan pada proses pembelajaran. Guru perlu memilih model pembelajaran yang tepat sehingga dapat meningkatkan aktivitas belajar, minat serta hasil belajar siswa (6). Satu model pembelajaran yang dianjurkan untuk digunakan dalam pembelajaran kurikulum 2013 adalah model project based learning. Model project based learning memberikan pengalaman belajar yang menarik dan bermakna bagi peserta didik. Sesuai dengan isi dalam Permendikbud nomor 103 Tahun 2014 yaitu, model pembelajaran yang digunakan berbasis aktivitas dengan karakteristik interaktif, inspiratif, menyenangkan, serta memotivasi peserta didik untuk dapat berpartisipasi aktif serta kontekstual dan kolaboratif. Model pembelajaran adalah kerangka konseptual/operasional, yang melukiskan prosedur yang sistematis dalam mengorganisasikan pengalaman belajar untuk mencapai tujuan belajar (7). Model pembelajaran yang diutamakan dalam implementasi Kurikulum 2013 adalah model pembelajaran Inkuiri (Inquiry Based Learning), model pembelajaran Discovery (Discovery Learning), model pembelajaran berbasis projek (Project Based Learning), model pembelajaran berbasis permasalahan (Problem Based Learning) (8).

Salah satu faktor yang mempengaruhi hasil belajar siswa adalah minat belajar. Minat individu peserta didik dalam belajar fisika, mempunyai pengaruh yang positif dalam pembelajaran fisika. Minat dapat diartikan sebagai aspek kepribadian yang berkaitan dengan hasil belajar, hal ini dikarenakan minat merupakan suatu kecenderungan untuk memperhatikan dan mengenal sesuatu (9). Minat berhubungan dengan tingkah laku, berorientasi pada objek, kegiatan atau pengalaman tertentu dan kecenderungan tersebut antara individu satu dengan yang lain sama intensitasnya. 
Berdasarkan uraian di atas, maka perlu untuk dilakukan penelitian dengan tujuan penelitian ini adalah: 1) Menentukan ada tidaknya hubungan yang signifikan antara minat belajar dengan hasil belajar fisika siswa melalui pembelajaran Project Based Learning (PJBL) pada siswa kelas XI MIPA SMA Negeri 6 Kota Bengkulu, dan 2) Menentukan seberapa besar hubungan antara minat belajar dengan hasil belajar fisika siswa melalui pembelajaran Project Based Learning (PJBL) pada siswa kelas XI MIPA SMA Negeri 6 Kota Bengkulu

\section{METODE PENELITIAN)}

Jenis penelitian yang diadopsi untuk menjawab permasalah penelitian adalah kuasi eksperimen dengan one-group pretest-posttest design yang dapat ditunjukkan pada tabel 1

Tabel 1. Desain Penelitian one-group pretest-posttest

\begin{tabular}{cccc}
\hline Kelas & Pretest & Perlakuan & Posttest \\
\hline Eksperimen & $\mathrm{O}_{1}$ & $\mathrm{X}$ & $\mathrm{O}_{2}$
\end{tabular}

Rancangan desain tersebut menjelaskan bahwa $\mathrm{X}$ adalah model pembelajaran berbasis proyek, $\mathrm{O}_{1}$ adalah pretest siswa, lalu untuk $\mathrm{O}_{2}$ merupakan skor posttest pada kelas ekperimen yang digunakan. Penelitian ini telah dilaksanakan pada semester genap tahun ajaran 2019/2020. Di SMAN 6 Kota Bengkulu. Populasi dalam penelitian ini adalah seluruh siswa kelas XI IPA SMA Negeri 6 Kota Bengkulu yang berjumlah 133 siswa. Penarikan sampel diperlukan namun berdasarkan dari populasi yang harus representative atau mewakili (10). Dengan pengambilan sampel berdasarkan teknik purposive sampling. Di samping itu, pertimbangan dari guru mata fisika kelas XI, ditetapkan bahwa kelas XI MIPA D dijadikan sebagai kelas sampel dengan syarat bahwa kondisi kelas memenuhi persyaratan normalitas. Adapun variabel penelitian ini terdiri dari variabel terikat dan variabel bebas. Dalam penelitian ini yang menjadi variabel bebas adalah adalah minat belajar fisika dan variabel terikat adalah hasil belajar fisika.

Teknik pengumpulan data berupa data minat belajar fisika dan hasil belajar diperoleh dari angket dan tes hasil belajar. Kedua instrumen dikembangkan dan dilakukan uji pakar (expert judment) serta uji emperik untuk mengkalibrasi kedua instrumen sebelum digunakan untuk alat pengumpul data penelitian.

Jenis angket yang digunakan adalah angket tertutup dengan menggunakan skala likert modifikasi dengan 4 jawaban alternatif pilihan jawaban Sangat Setuju ( $S S=4)$, Setuju ( $S=3$ ), TidakSetuju (TS=2), dan Sangat Tidak Setuju (STS = 1). Sebanyak butir angket terdiri dari 22 pernyataan positif dan 18 pernyataan negatif dan dikembangkan dengan berpedoman pada empat indikator minat belajar adalah ketertarikan, perhatian, perasaan senang, dan keterlibatan siswa dalam belajar fisika (11).

Instrumen penelitian sebelumnya dilakukan validasi oleh tiga orang. Sebelum uji cobakan dilakukan, instrumen divalidasi oleh dua dosen fisika dan satu dibawa oleh guru. Penilaian ahli dilakukan untuk menentukan validitas isi (content validity) pada aspek relevansi dengan indikator pembelajaran, kejelasan dan keterbacaan kalimat/istilah dalam butir tes. Data hasil uji coba dianalisis untuk menentukan validitas butir tes (Product Moment Pearson), reliabilitas instrumen (Alpha Cronbach), tingkat kesukaran dan daya pembeda butir soal.

Teknik analisis data instrument berupa angket minat belajar dan soal tes hasil belajar dianalisis secara analisis deskriptif (mean, standar deviasi, dan $N$-gain) dan analisis statistik inferensial uji normalitas). Perhitungan $\mathrm{N}$-gain dilakukan untuk mengetahui seberapa besar peningkatan minat belajar fisika dan hasil belajar dapat dihitung dengan menggunakan persamaan 1 berikut.

$$
N-\text { Gain }=\frac{\text { nilai posttest-nilai pretest }}{\text { nilai maksimal-nilai pretest }}
$$

Hasil perhitungan gain ternormalisasi yang didapatkan selanjutnya diinterpretasi berdasarkan tabel 2 interpretasi $\mathrm{N}$-gain (12) 
Tabel 2. Kriteria Pengelompokkan N-Gain

\begin{tabular}{cc}
\hline N-Gain & Kriteria \\
\hline $\boldsymbol{g} \geq \mathbf{0 . 7}$ & Tinggi \\
$\mathbf{0 . 3} \leq \boldsymbol{g} \leq \mathbf{0 . 7}$ & Sedang \\
$\boldsymbol{g} \leq \mathbf{0 . 3}$ & Rendah \\
\hline
\end{tabular}

Selanjutnya penggunaan juga dilakukan pada analisis statistik inferensial agar memenuhi syarat untuk ke tahap selanjutnya yaitu uji hipotesis berupa analisis korelasi sederhana dan analisis regresi linier sederhana. Adapun hipotesis penelitian ini adalah (1) $\mathrm{H}_{0}$ : Tidak ada hubungan yang signifikan pada minat belajar dengan hasil belajar fisika siswa melalui Model Project Based Learning (PJBL) pada siswa kelas XI MIPA SMA Negeri 6 Kota Bengkulu. (2) $\mathrm{H}_{a}$ : Terdapat hubungan yang signifikan pada minat belajar dengan hasil belajar fisika siswa melalui Model Project Based Learning (PJBL) pada siswa kelas XI MIPA SMA Negeri 6 Kota Bengkulu.

\section{HASIL DAN PEMBAHASAN}

\subsection{Hasil Penelitian}

Penelitian diawali dengan penyusunan instrumen penelitian berupa angket minat belajar mengacu kepada indikator minat belajar yang diteliti, diantaranya adalah perhatian, perasaan senang, ketertarikan dan keterlibatan siswa dan instrumen soal tes hasil belajar. Selanjutnya angket minat belajar maupun soal tes hasil belajar dilakukan uji validitas dan uji reliabilitas ditambah uji tingkat kesukaran dan daya pempeda soal dengan diikuti sebanyak 30 siswa. Data hasil uji validitas dan reliabilitas angket minat belajar siswa yaitu 40 butir pernyataan dinyatakan valid dengan besar reliabilitas yaitu 0,886 sedangkan untuk soal tes hasil belajar 17 soal valid dari 18 soal yang diajukan dengan nilai reliabilitas 0,910. Selanjutnya daya pembeda yang digunakan untuk membedakan siswa yang berkemampuan rendah dan siswa yang berkemampuan tinggi. Untuk hasil daya pembeda didapatan 14 soal dikategori cukup dan 4 soal dikategori jelek. Untuk tingkat kesukaran soal, terdapat 8 soal dikategori sedang dan 10 soal dikategori mudah. Jika salah satu tidak memenuhi kriteria maka soal tersebut tidak dapat digunakan di lapangan.

Pelaksanaan proses pembelajaran berlangsung selama empat kali pertemuan masing-masing dua pertemuan yang digunakan untuk mengerjakan 1 proyek dengan menggunakan model Project Based Learning. Sebelum dimulainya belajar siswa diberi pretest terlebih dahulu. Pelaksanaan model Project Based Learning dilaksanakan dengan enam tahap. Adapun tahapnya terdiri dari a) penentuan proyek, 2) perencanaan proyek, 3) menyusun jadwal penyelesaian proyek, 4) penyelesaian proyek dengan memonitor siswa, 5) presentasi hasil proyek, 6) evaluasi proses dan hasil proyek (7).

Selanjutnya dilakukan analisis deskritif untuk mendeskripsikan hasil minat belajar dan hasil belajar fisika siswa kelas eksperimen menggunakan model project based learning. Perolehan skor minat belajar fisika di kelas eksperimen diperoleh data pada Tabel 3

Tabel 3. Analisis deskriptif minat belajar fisika kelas eksperimen

\begin{tabular}{|c|c|c|}
\hline \multirow{2}{*}{ Data yang dianalisis } & \multicolumn{2}{|c|}{ Nilai statistik kelas eksperimen } \\
\hline & Pretest & Posttest \\
\hline Rata-rata & 44.77 & 59.79 \\
\hline Standar deviasi & 9.1 & 5.87 \\
\hline N-Gain & \multicolumn{2}{|c|}{0.431} \\
\hline
\end{tabular}

Berdasarkan Tabel 3, diketahui bahwa nilai pretest dan posttest minat belajar siswa meningkat dari rata-rata pretest sebesar 44,77 menjadi 59,79. Hal tersebut juga dapat dilihat dari nilai N-Gain nya sebesar 0,431 dan dikategorikan sedang sesuai tabel 2.

Sedangkan perolehan skor tes hasil belajar siswa di kelas eksperimen dapat dilihat pada tabel 4

Tabel 4. Analisis Deskritif Hasil Belajar Fisika Kelas Eksperimen

\begin{tabular}{ccc}
\hline \multirow{2}{*}{ Data yang dianalisis } & \multicolumn{2}{c}{ Nilai statistik kelas eksperimen } \\
\cline { 2 - 3 } & Pretest & Posttest \\
\hline Rata-rata & 39.05 & 77.71 \\
\hline
\end{tabular}




\begin{tabular}{|c|c|c|}
\hline \multirow{2}{*}{ Data yang dianalisis } & \multicolumn{2}{|c|}{ Nilai statistik kelas eksperimen } \\
\hline & Pretest & Posttest \\
\hline Standar deviasi & 10.57 & 9.78 \\
\hline N-Gain & \multicolumn{2}{|c|}{0.634} \\
\hline
\end{tabular}

Berdasarkan Tabel 4, diperoleh rata-rata pretest hasil belajar fisika mencapai 39.5 setelah diberi perlakuan rata-rata posttest meningkat menjad 77.71 hal tersebut juga terlihat pada nilai $\mathrm{N}$-Gain sebesar 0.634 dan dikategorikan sedang.

\subsection{Uji Inferensial}

Selain diuji dengan analisis deskripsi, data juga dianalisis dengan analisis inferensial yaitu berupa uji normalitas dengan menggunakan uji Chi-Square. Hasil pengujian normalitas minat belajar fisika dan hasil belajar fisika siswa dapat dilihat dari Tabel 5.

Tabel 5. Data Hasil Uji Normalitas

\begin{tabular}{ccccc}
\hline Kelas & Data & $x^{2}$ hitung & $x^{2}$ tabel & $\begin{array}{c}\text { Distribusi } \\
\text { Data }\end{array}$ \\
\hline \multirow{3}{*}{ Eksperimen } & Pretest minat belajar & 9.67 & 11.07 & Normal \\
& Posttest minat belajar & 4.10 & 11.07 & Normal \\
& Pretest hasil belajar & 9.44 & 11.07 & Normal \\
& Posttest hasil belajar & 2.59 & 11.07 & Normal \\
\hline
\end{tabular}

Data yang berdistribusi normal apabila $x^{2}$ hitung $<x^{2}$ tabel pada taraf signifikansi ( 0.05) Berdasarkan data yang dituliskan pada tabel tersebut maka diperoleh bahwa $x^{2}$ hitung $<x^{2}$ tabel dengan kesimpulan bahwa data tersebut terdistribusi normal.

\subsection{Uji Hipotesis}

Dikarenakan persyaratan untuk dilakukannya uji hipotesis dipenuhi, maka uji hipotesis dapat dilanjutkan dengan uji korelasi product moment dan uji regresi linier sederhana.

\section{Koefisien korelasi}

Berdasarkan hasil perhitungan, diperoleh hasil koefisien korelasi $\left(r_{x y}\right)$ atau rhitung sebesar 0,660 dengan taraf signifikansi $(\alpha)=0,01$ dan jumlah responden $(n)=28$ siswa, sehingga diperoleh rtabel sebesar 0.479. Dari hasil perhitungan tersebut menunjukkan bahwa rhitung > rtabel, maka dapat disimpulkan hipotesis alternatif (Ha) diterima yaitu terdapat hubungan positif antara minat belajar fisika (X) dan hasil belajar siswa (Y) kelas XI MIPA D SMA Negeri 6 Kota Bengkulu. Dilihat pada tabel 6 dibawah ini

Tabel 6. Hasil Perhitungan Koefisien Korelasi

\begin{tabular}{|c|c|c|c|c|c|c|}
\hline Kelas & Hasil & $\mathbf{N}$ & Rata-Rata & $\mathbf{r}_{\text {hitung }}$ & $\mathbf{r}_{\text {tabel }}$ & Kesimpulan \\
\hline $\begin{array}{c}\text { XI MIPA } \\
\text { D }\end{array}$ & $\begin{array}{c}\text { Posttest } \\
\text { minat } \\
\text { Postest } \\
\text { Hasil } \\
\text { belajar }\end{array}$ & 28 & 59.893 & 0.660 & 0.479 & $\begin{array}{c}\text { Terdapat } \\
\text { Hubungan } \\
\text { Positif }\end{array}$ \\
\hline
\end{tabular}

\section{Analisis Koefisien Determinasi (KD)}

Analisis koefisien determinasi digunakan untuk menyatakan seberapa besar atau kecilnya sumbangan variabel $\mathrm{X}$ terhadap Y. Nilai koefisien determinasi ( $R$ Square) yang didapat adalah sebesar 0,435 yang berarti bahwa kontribusi dari variabel bebas berupa minat belajar kimia terhadap variabel tetap hasil belajar sebesar 43,56\%, yang membuktikan bahwa minat belajar memiliki pengaruh yang besar terhadap hasil belajar.

\section{Uji Regresi Sederhana}

Analisis regresi sederhana digunakan sebagai prediksi dari hubungan analisis korelasi. Hasil untuk uji regresi linier menunjukkan bahwa persamaan regresi yang didapat adalah : $\hat{\mathrm{Y}}=\mathrm{a}+\mathrm{bX}$ dengan 
$a=11.7$ dan $b=1.1$ sehingga didapatkan untuk persamaan regresi liniernya adalah $\hat{\mathrm{Y}}=11.7+1.1 \mathrm{X}$. $\mathrm{Y}$ adalah hasil belajar fisika dan X adalah Minat belajar. Untuk mengetahui derajat keberartian dan linearitas persamaan regresi sederhana dilakukan uji $\mathrm{F}$. Berdasarkan persamaan diatas, maka apabila minat belajar meningkat satu unit maka hasil belajar akan meningkat sebesar 1,1 pada konstanta 11,7 .

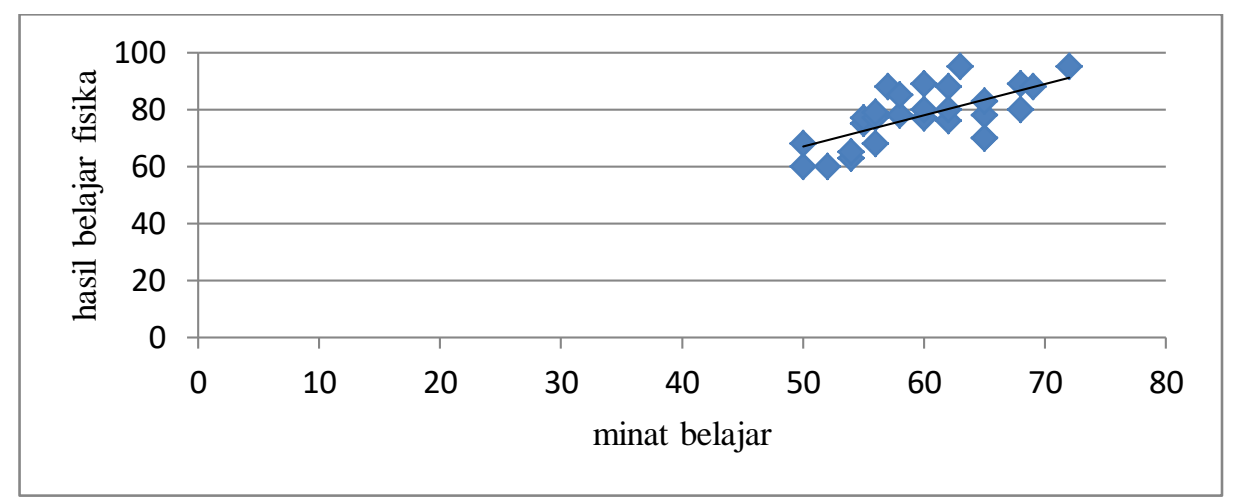

Gambar 1. Grafik Uji Regresi Linier Sederhana

Pada gambar 1, dapat diperoleh bahwa antara minat belajar dan hasil belajar fisika membentuk hubungan yang linier sesuai dengan grafik dengan persamaan $\hat{\mathrm{Y}}=11.7+1.1 \mathrm{X}$.

\subsection{Pembahasan}

Berdasarkan hasil penelitian yang diperoleh membuktikan bahwa model pembelajaran yang diterapkan oleh guru di kelas sangat berperan penting dalam proses pembelajaran. Cara pembelajaran yang dilakukan oleh guru di dalam kelas sangat mempengaruhi peningkatan minat dan hasil belajar siswa (13). Tidak semua materi fisika dapat digunakan untuk menerapkan model project learning. Pelaksanaan model PjBL, dikerjakan secara berkelompok dan akan lebih menarik jika suasana ruang belajar yang tidak monoton dan suasana belajar yang menyenangkan bahkan saat diskusi dapat dilakukan di taman, artinya belajar tidak harus dilakukan di dalam kelas. Dengan adanya komunikasi antar kelompok maka proses pembelajarannya terjadi hubungan antar siswa yang saling bekerja sama dengan anggotanya, saling mendukung, bekerja sama, dan bertanggung jawab terhadap tugas masing-masing yang telah disepakati bersama. Model PjBL dilakukan melalui 6 langkah yaitu : Penentuan proyek, Mendesain Perencanaan perancangan Proyek, Menyusun Jadwal proyek, penyelesaian proyek dengan fasilitasi dan monitoring guru, presentasi hasil proyek, Mengevaluasi proyek dan hasil proyek.

Minat merupakan suatu rasa suka dan rasa ingin tahu pada suatu hal atau aktivitas, tanpa ada yang menyuruh. Minat berarti kecenderungan dan kemauan yang tinggi atau keinginan yang besar terhadap sesuatu (14). Minat belajar merupakan salah satu indikator keberhasilan anak dalam belajar. Hal ini didukung berdasarkan perolehan skor untuk kelas eksperimen yang menunjukan bahwa rata-rata skor minat belajar fisika siswa lebih meningkat. Hal ini juga sesuai dengan penelitian sebelumnya oleh permata (15) dan juga dengan pendapat Slameto yang menyatakan bahwa minat sebagai faktor internal siswa merupakan salah satu faktor yang akan mempengaruhi hasil belajar (16). Minat belajar dapat dilihat dari beberapa indikator minat, antara lain yaitu rasa suka/senang, perhatian, ketertarikan dan keterlibatan peserta didik. Besarnya nilai rata-rata korelasi yang diperoleh dari masing-masing indikator minat belajar pada siswa di SMAN 6 Kota Bengkulu dapat dilihat pada Tabel 7

\begin{tabular}{|c|c|c|}
\hline No & Indikator Minat & Nilai rata-rata korelasi \\
\hline 1 & Perasaan senang & 0.669 \\
\hline 2 & Perhatian & 0.407 \\
\hline 3 & Ketertarikan & 0.489 \\
\hline 4 & Keterlibatan peserta didik & 0.595 \\
\hline
\end{tabular}

Dari data Tabel 7, terlihat bahwa bahwa indikator minat yang paling besar pengaruhnya terhadap hasil belajar siswa adalah pada indikator perasaan senang dengan nilai korelasi 0.669 
sedangkan indikator yang paling keciil pengaruhnya adalah pada indikator perhatian dengan nilai korelasi 0.407.

Hasil belajar adalah gambaran kemampuan siswa dalam memenuhi suatu tahapan pencapaian pengalaman belajar dalam satu kompetensi dasar (2). Hasil belajar juga dapat diartikan sebagai kemampuan yang diperoleh anak setelah melalui kegiatan belajar (17). Hasil belajar siswa juga ditentukan oleh peran seorang guru dalam proses pembelajaran. Peran guru sebagai motivator dan fasilisator dalam proses pembelajaran sangat membantu siswa dalam belajar. Peningkatan hasil belajar ini terjadi karena guru telah melakukan perbaikan-perbaikan atas masalah yang masih ditemukan dalam proses pembelajaran (18). Untuk pencapaian skor rata-rata posttest lebih besar ketika sesudah diberi perlakuan daripada nilai pretest sebelum diberi perlakuan.

Adapun hasil penelitian yang relatif relevan mengenai hubungan minat hasil belajar dengan hasil belajar yaitu yang dilakukan oleh Jaba dengan judul Hubungan Minat Belajar dengan Prestasi Belajar Fisika Siswa Kelas XI IPA SMA Negeri 2 Merauke (19) menunjukan bahwa hasil minat belajar siswa terdapat hubungan yang signifikan antara minat belajar dengan pretasi belajar fisika dengan nilai t hitung lebih besar daripada t rabel yaitu hasil perhitungan korelasi diperoleh nilai 0,337 dengan persentase pengaruh variabel independennya sebesar 11,35\%,. Selain Jaba, juga dilakukan oleh Ritongga dengan judul Hubungan Minat Belajar Dan Konsep Diri Terhadap Prestasi Belajar Siswa (20) yang menyimpulkan adanya hubungan positif dan signifikan antara minat belajar terhadap prestasi belajar siswa dari hasil korelasi uji $\mathrm{r}$ Nilai koefisien korelasi sebesar 0,553 membuktikan minat belajar dan konsep diri memberikan kontribusi sebesar 55,3\% terhadap prestasi belajar siswa.

\section{SIMPULAN DAN SARAN}

\subsection{Kesimpulan}

Berdasarkan hasil penelitian dapat disimpulkan sebagai berikut: 1) Terdapat hubungan positif yang signifikan antara minat belajar dengan hasil belajar fisika siswa melalui pembelajaran Project Based Learning (PjBL) pada siswa kelas XI MIPA D SMA Negeri 6 Kota Bengkulu dengan nilai korelasi product moment sebesar 0,660 dengan taraf signifikan $(\alpha=0,01)$. 2) Besarnya sumbangan atau kontribusi minat belajar dengan hasil belajar fisika siswa sebesar 0.435 yang artinya $43.56 \%$ hasil belajar fisika siswa (Y) ditentukan oleh minat belajar (X).

\subsection{Saran}

Sebagai saran, diharapkan guru dapat menerapkan model Project Based Learning dalam pembelajaran pada materi yang mengandung penugasan proyek, seperti momentum, dan fluida dinamis. Penelitian ini selanjutnya diharapkan dapat dilaksanakan untuk mengetahui perbedaan pengaruh pada pokok bahasan yang sama dan jenjang sekolah yang sama sehingga dapat mengukur sejauh mana keefektifan penggunaan model project based learning. Untuk peneliti yang ingin menerapkan model pembelajaran project based learning diharapkan kejelian dalam memanajemen waktu, biaya serta peralatan yang harus disediakan agar dalam proses pembelajaran dapat berjalan dengan efektif dan efisien.

\section{UCAPAN TERIMA KASIH}

Penulis mengucapkan terimakasih kepada Validator ahli yang sudah bersedia untuk membantu memvalidasi instrument penelitian. Penulis juga berterimakasih kepada Kepala Sekolah dan guru mata pelajaran fisika SMA Negeri 6 Kota Bengkulu serta kepada siswa dan siswi kelas XI MIPA D yang telah bersedia untuk memberi dukungan, memberikan fasilitas dan turut membantu selama proses penelitian berlangsung.

\section{DAFTAR PUSTAKA}

1. Mendikbud. Peraturan Menteri Pendidikan Nasional dan Kebudayaan Nomor 20 Tahun 2003 Tentang Sistem Pendidikan Nasional. 2003 p. 1-38.

2. Sanjaya W. Kurikulum dan Pembelajaran. Jakarta: Kencana; 2008. 
3. Putri DH, Risdianto E, Sutarno S. Pre-Service Physics Teachers' Perception toward Handson Lab Activity and 21st Century Skills. J Phys Conf Ser. 2017;895(1).

4. Putri DH, Risdianto E, Sutarno S, Hamdani D. The development of cooperative problem solving physics laboratory model on simple pendulum concept The development of cooperative problem solving physics laboratory model on simple pendulum concept. 2019;

5. Monika Y, Mayub A, Purwanto A. Pengaruh Project Based Learning (PJBL) Model Terhadap Penguasaan Konsep Fisika Pada Siswa Kelas X SMA Negeri 1 Kota Bengkulu. J Kumparan Fis. 2018;1(2):25-30.

6. Sagita I, Medriati R, Purwanto A. Penerapan Creative Problem Solving Model untuk Meningkatkan Kemampuan Pemecahan Masalah Fisika Siswa Kelas XI MIA 4 MAN 2 Kota Bengkulu. J Kumparan Fis. 2018;1(3):1-6.

7. Hosnan M. Pendekatan Sintifik dan Kontekstual dalam Pembelajaran Abad 21. Bogor: Ghalia Indonesia; 2016.

8. Permendikbud. Permendikbud Nomor 22 Tahun 2016 Tentang Standar Proses Pendidikan Dasar dan Menengah. Jakarta: Kemendikbud; 2016.

9. Rozikin, MK., Lesmono, AD. B. Pengaruh Model Pembelajaran Berbasis Proyek ( Project Based Learning ) Terhadap Minat Belajar dan Keterampilan Proses Sains Siswa Pada Pembelajaran Fisika di SMAN Balung. 2018;108-15.

10. Sugiyono. Metode Penelitian Pendidikan. Bandung: Alfabeta; 2010.

11. Sriana W. Hubungan Minat Belajar Dengan Hasil Belajar Mata Pelajaran Tata Busana di Madrasah Aliyah Negeri 2 Padang. 2013;

12. Hake RR. Analyzing change/gain scores. Woodland Hills: Dept of Physics: Indiana University; 1999. 1-4 p.

13. Medriati R. Upaya Peningkatan Hasil Belajar Fisika Siswa Pada Konsep Cahaya Kelas VII6 Melalui Penerapan Model Pembelajaran Problem Based Learning ( PBL ) Berbasis Laboratorium di SMPN 14 Kota Bengkulu. Pros Semirata FMIPA Univ Lampung 2013. 2013;131-9.

14. Kompri. Belajar dan Faktor-faktor yang Mempengaruhinya. Yogyakarta: Media Akademi; 2017.

15. Permata MD, Koto I, Sakti I. Pengaruh Model Project Based Learning terhadap Minat Belajar Fisika dan Kemampuan Berpikir Kritis Siswa SMA Negeri 1 Kota Bengkulu. J Kumparan Fis. 2019;1(1):30-9.

16. Slameto. Belajar dan Faktor -faktor yang Mempengaruhi. Jakarta: Rineka Cipta; 2010.

17. Fadilah S, Purwanto A, Risdianto E. Penerapan Model Inkuiri Terbimbing Untuk Meningkat Sikap Ilmiah Dan Hasil Belajar Siswa Pada Konsep Alat-Alat Optik Kelas XI SMAN 1 Mukomuko. J Kumparan Fis. 2018;1(2):8-14.

18. Adyan FB, Purwanto A, Nirwana N. Upaya Meningkatkan Motivasi Dan Hasil Belajar Siswa Dengan Model Discovery Learning Berbantuan Virtual Laboratory. J Kumparan Fis. 2019;2(3):153-60.

19. Jaba I, Palittin vyalentine D, Nur AS. Hubungan Minat Belajar Dengan Prestasi Belajar Fisika Siswa Kelas XI IPA SMA Negeri 2 Merauke. 2019;6(1):65-73.

20. Ritonga MFM. Hubungan Minat Belajar dan Konsep Diri Terhadap Pretasi Belajar Siswa. 2017;70-6. 